\title{
DISJUNCTIVE SYNTHESES OF (POST)DIGITAL ARCHITECTURE AND LIFE
}

\author{
HÉLÈNE FRICHOT \\ Program of Architecture \\ School of Architecture and Design \\ RMIT University, Melbourne \\ 360 Swanston St, Melbourne, VIC 3001, Australia \\ helene.frichot@rmit.edu.au
}

\begin{abstract}
In her recent book, Architecture, Animal, Human: The Asymmetrical Condition, Catherine Ingraham maintains a stalwart asymmetry between, on the one hand, human, animal and other life, and on the other hand, the material constraints or framed enclosures of architecture. When we turn to the recent, speculative work of the Emergence and Design Group (Michael Hensel, Michael Weinstock, and Achim Menges) we find a practice that deploys the software of computer technologies as a medium that has become increasingly life-like in its operational capacities and engagements. Rather than an asymmetrical condition, digital architects, such as the Emergence and Design Group, appear to be dismantling the distinction between architectural form and human, animal and other life forms. What we are asked to imagine is a continuum that unfolds in both directions, one infecting the other, organic interpenetrating inorganic, technology intertwined with biological life. What's more, the resulting hybrid of architecture-cum-life in (de)formation, should be apprehended as animated and ever-responsive to the field from which it emerges. The formal complexity that supposedly results erupts unexpectedly from a plane of continuous variation where the emphasis lies in the surface effect. This paper will trace the legacy of the work of Gilles Deleuze and Félix Guattari with respect to key conceptual moves, implicit and explicit, being made by so-called digital architects. Following what can be identified as Deleuze and Guattari's ethics of immanence, this paper will also consider whether an appropriate ethico-aesthetic practice can be engaged to address what appears to be a new architectural paradigm with its attendant desire for an intimate proximity with life.
\end{abstract}

Keywords: (post)digital architecture, life, ethico-aesthetics, disjunctive synthesis.

\section{Introduction}

Techniques associated with contemporary experimental architectures undertaken in what could be called a (post)digital milieu are increasingly drawing on the now well-established crossfertilisation of ideas between computer science (animation, modelling, informatics, computation) and biological science (evolutionary science, genetics, also biochemical science). If we were to render today a list of symptoms that pertain to the current engagement of the discipline of architecture with the above conjunction, conceived as a bio-technogenesis of the ever-evolving 
human condition, we would find that the large question of life, and a vested relationship between architecture and life, recurs across contemporary architectural discourse and production. While architect and theorist, Greg Lynn is regularly identified as a key figure in the artificial animation by computational means of architecture, more recent collaborations such as the Emergence and Design Group (Michael Hensel, Michael Weinstock, and Achim Menges), have begun to explore how architecture, one day soon, will literally respond to life criteria. According to Michael Hensel and Achim Menges, we have much to learn from the chemical reactions that occur across the flexible membranes of cell walls, as well as their associated material infrastructures. American architectural theorist, Catherine Ingraham, on the other hand, prefers to consider things without the aid of augmented vision. The relationship between architecture and life that she posits in her recent book, Architecture, Animal, Human: The Asymmetrical Condition, maintains a stalwart asymmetry between, on the one hand, human, animal and other life, and on the other hand, the material constraints or framed enclosures of architecture. Where Ingraham's vision from the middle distance offers a helpful overview, the close vision (literally life magnified) of the Emergence and Design Group threatens a collapse with respect to our ability to create what might turn out to be useful differentiations. Nevertheless, this paper will elaborate on the close molecular vision of Michael Hensel et al, as different, yet potentially continuous with the view at a middle distance offered by Ingraham through her historical and theoretical study. To call forth this notion of a heterogeneous continuity between the two points of view on the matter, it will be necessary to return to the conceptual legacy of philosopher, Gilles Deleuze and psychoanalyst, Félix Guattari who unveil an organization of life from another point of view altogether, one that is composed of multitudinous points of view.

Although histories of architecture reveal marvelous displays of the various means by which natural forms have been emulated through the force of human labour, what is remarkable about contemporary developments is the focus not only on biological process over the conceptual illusion of fixed natural form, but on the suggestion that architecture will become living, evertransforming, or morphogenetic organism in profound, symbiotic relationship with environmental context. Metaphor has given way to metamorphosis. It is necessary to turn our attention to the microscopic, even atomic scale of a world to comprehend possibilities of continuity between what, at the mere human scale of things seems to constellate in patterns of organic and inorganic array. The symptomatology I mention in my introduction draws us to a great surface that unfurls, showing constellations of vital signs, many of which conceal a legacy that is indebted to the writings of Deleuze and Guattari. Their creative philosophy, framed most explicitly in their final collaborative work, What is Philosophy? forwards not only a pragmatic aesthetics, but a radical ethics of immanence. Their philosophy demands the examination of contemporary problematic fields and the necessity of framing adequate questions. That is to say, they are less interested in meaning and more interested in use, and how things work in relation to each other such that virtual life capacities can be increased rather than reduced.

This paper forms part of a broader project that is in pursuit of an active ethico-aesthetics that draws on the legacy of Deleuze and Guattari, one that can be engaged in the application of reconfigured techniques that emerge out of the eruptive conjunction of the three disciplines of computer science, biology and architecture. Here I will also ask what is at stake in the complicated encounter between architecture and life. It is necessary to admit that there is nothing new in asking such a question, except that each time we address the question of a life it will have necessarily shifted; new developments in technology and the emergence, as well as the disappearance of ever-new life worlds and life forms demands the reframing of pertinent, context relevant questions. What's more, the constant reframing of problematic fields contributes to an active ethics. The disjunctive synthesis of my title suggests that life and architecture are perpetually drawn to each other, into an embrace, only to withdraw again transformed following the encounter. A disjunctive synthesis also describes processes of differenc/tiation that operate across shifts in scale, and from any number of minor points of view. The conceptual oscillation that circulates in this word of undecided spelling demands that we accept, simultaneously, the determination of the virtual content of an idea and how this comes to be actualised as a species, or parts of some object or organism. As Deleuze explains in Difference and Repetition, "It is always a problematic field which conditions a differenciation within the milieu in which it is incarnated" (207). Where the virtual (animating force of life) lays out a field of potentiality (differentiation), that which comes to be actualised (the object, subject, organism) makes virtual life visible, and gives it materiality (differenciation). 


\section{The Morpho-Ecological Approach}

Experimental practitioners such as the Emergence and Design Group propose an optimistic and purportedly unproblematic identification between architecture and life, such that architecture promises to become living organism. In $A D$ : Techniques and Technologies they write: "the currently prevailing biological paradigm is taken to its most literal extreme in a enquiry into the consequences of understanding architectures as living entities and the potential benefits of applying life criteria to architecture" (6). The Emergence and Design Group describe an important shift in our architectural understanding of the world that places us in direct contact with what they call the biological paradigm. At the same time, cognisant of historical influence, they pay tribute to the important research of such figures as German engineer, Frei Otto, and through Mark Burry, they pay homage to Antonio Gaudi, amongst others. While Ingraham's account offers us a history of the relationship between the disciplines of architecture and biology that returns us to their respective formation as identifiable bodies of knowledge, the Emergence and Design Group are more interested in forwarding a manifesto that becomes most clear in their latest collaborative publication, Morpho-Ecologies. The opening essay, Towards an Inclusive Discourse on Heterogeneous Architectures sketches out a manifesto of sorts, where the "ME [morpho-ecological] approach" is articulated in relation to seven or eight key points, from the rejection of Newtonian physics to the uptake of morphogenetic systems, the deliberate differentiation of material systems, and the emphasis on the construction of material models, and so on. In the preliminary remarks the reader is encouraged to use the book less for contemplating than for using; it is a manual for the explorative designer. What the biological paradigm apparently allows the designer is a material return from the pure electronic realm of digital computation. This return does not constitute a mere retreat to hand-crafted techniques, instead material model-making techniques are clenched with immaterial computational explorations in a feedback loop where neither is supposed to be privileged. The biological paradigm allows us to see how these techniques reflect the way organism and environment also involve and evolve simultaneously.

Though not directly responding to the work of the Emergence and Design Group, the current problem that Ingraham identifies is that "Architecture begins to mistake itself for an organism and life for a technology" (27). Such mistakes, she continues, describe the aspirations of certain domains of current architectural work. Architects employing computational processes that crossover into biological models and processes have mostly forgotten the slow movement of evolutionary becoming and have placed their bets instead on the speed enhancing drugs of new technologies. For instance, we hear Hensel et al insisting "a crucial aspect of this approach is the emphasis on process and the acceleration of an architectural environment" (2006: 58). Here we could also list the work of Foreign Office Architects (foa), Greg Lynn's studio, Form, and Lars Spuybroek's studio, NOX. John's Frazer's work, framed in An Evolutionary Architecture, should also be noted as an earlier development of some of this contemporary exploration. What is remarkable about many of these practices is that their associated discursive production is peopled by architectural theorists many of whom remain fundamentally indebted to the work of Deleuze and Guattari, for instance, Manuel de Landa and Brian Massumi appear in publications by both Foreign Office Architects (2003) and NOX (2004). The Emergence and Design Group, on the other hand, remain far more earnest as they deploy a language that is quasi-scientific and cleansed of distracting references to the like of Deleuze and Guattari. What's more, they do not intend any level of metaphoricity, as user's guide, Morpho-Ecologies is directed at the student and practitioner of architecture as a manual of ready to go techniques.

\section{$3 \quad$ Error and Life}

If conceptual mistakes are being made in the argumentation that supports all the furious architectural activity that currently celebrates the new biological paradigm, this is not necessarily all bad. Michel Foucault reminds us that life can be seen to proceed according to error: "in a sense, life - and this is its radical feature - is that which is capable of error" $(1994,476)$. Especially when it comes to man, Foucault elaborates, what we have is a living being perpetually out of place and mistaken. Why else do we find it necessary to constantly correct the drift of knowledge? Error and life together create the necessity of chance processes, a productive paradox. Error considered as the chance or aleatory encounter allows the connection of what might have first seemed disparate domains, for instance, computer science and biology, and then, more recently, the entry of (post)digital architecture into the fray, alongside advanced engineering technologies. What is frequently forgotten is how biotechnological research profoundly impacts on ontological identifications. Our bio-technological 
capacity promises to change who we are as well as the milieu (a world, a habitat) in which we are intimately imbricated.

The new paradigm that the Emergence and Design Technology Group frame identifies biology, the scientific and rational study of life forms and processes of formation as a key partner to architectural investigation. Ingraham argues that what such groups do not adequately study is how the life sciences have an ontological impact on the status of human, animal and other life (2006, 94). In engaging a new epistemological paradigm, to what extent is the human and other occupant likewise ontologically transformed? Too often design process as open-ended experiment in continuity with a 'natural world' forgets the very peculiar fact of the (post)human subject who is perhaps denatured. With respect to the project for a new biological paradigm that the Emergence and Design Group forward, we can innumerate an index of theoretical forgetfulness: 1.) The organism is resolutely left in place. While life forms are transformed through the processes of morphogenesis, organisms remain organized, recognizable and characterized from an anthropocentric point of view. The organized organism also forgets the liberatory and ethical promise of the BwO (Body without Organs) that Deleuze and Guattari forward in their first collaborative work, Anti-Oedipus. 2.)The organism is assumed to be 'normal'. Have we forgotten Georges Canguilhem, and in turn, his student, Michel Foucault's critique of the distinction between the normal and pathological? 3.) The fear of the monstrous. Foucault writes "It has not been possible to constitute a science of the living without taking into account, as something essential to its object, the possibility of disease, death, monstrosity, anomaly, and error" $(1994,474)$. 4.) The vitalism of life is stressed, but rarely do we hear much talk about death. Life is privileged over death, which is to forget the co-presence and coproduction of life and death processes. Though I cannot expand on this brief index of theoretical forgetfulness here, it is worth asking what is lost in the shift from one discursive mode to the next, from architectural-theoretical to architectural-techno-scientific.

We habitually forget that for the most part these issues come down to a question of scale and point of view. As Menges and Achim point out, "ecology can be studied at various levels ranging from the individual organism to populations, communities of species, ecosystems and the biosphere" (2006 54). At the molecular level it can seem as though all life belongs to a molecular continuum, which nonetheless perpetually differentiates and unfurls, folding and unfolding through one material composition into another. Matter, as Deleuze argues "thus offers an infinitely porous, spongy, or cavernous texture without emptiness, caverns endlessly contained in other caverns: no matter how small each body contains a world pierced with irregular passages, surrounded and penetrated by increasingly vaporous fluid" $(1993,5)$. Perhaps we could pause for a moment and consider the world from the point of view of a tick, and consider the ethical lesson Deleuze suggests can be discovered therein. Deleuze and Guattari make occasional reference to the biologist Jakob von Uexküll (1864-1944) to account for the construction of different life-worlds through which living forms unfurl.

\section{$4 \quad$ Life From the Point of View of a Tick}

From ever-folding and unfolding distributions of matter there persists the level of human life and its construction of world(s). We see that architecture is distinct from life and frames inhabitation, but this only from a human point of view. There are also multitudinous animal worlds to which we have no access. It is by a detour through Deleuze and Guattari, for instance, that the biologist, Uexküll's ethology is rediscovered. Uexküll's vision of the fleeting life of the blind tick leaping onto its prey is also recounted in both the work of Giorgio Agamben and Ingraham. What's more, the "ME Approach" captures the work of this Estonian biologist to explore his theory of the Umwelt (environment-world) as that milieu composed of so many incommensurable, subjectively selected, viewed and constructed worlds. This assists the Emergence and Design Group in their discussion of how individuals interact with their environment, nevertheless, the individual in question remains intact through this encounter. Deleuze suggests that the tick and its world can be defined by three affects: "the first has to do with light (climb on top of branch); the second is olfactive (let yourself fall onto mammal that passes beneath the branch); and the third is thermal (seek the area without fur, the warmest spot)" (1988b 124; see also 1987,51 ). This is a world with only three affects, which together contribute to the setting of an optimal threshold and a pessimal threshold of existence. The tick is by no means lesser on account of having so few affects; the tick makes the best of what is available to it. Importantly, "no one knows ahead of time the affects one is capable of; it is a long affair of experimentation requiring a lasting prudence" (Deleuze, 1988b, 125). Isolated and insular human and animal environment-worlds, framed by restricted, monadic points of view are not adrift but conjoined by the virtual, pre-individual plane of immanence. Agamben describes 
Uexküll's schema as follows "an infinite variety of perceptual worlds that, though they are uncommunicating and reciprocally exclusive, are all equally perfect and linked together as if in a gigantic musical score" (40). It is a decidedly non-anthropomorphic view of multitudinous environment-worlds or Umwelts. The human world in this schema is given no privilege, and varies according to the point of view from which we observe it. What Deleuze calls affects Agamben calls "carriers of significance"(46). The task of the researcher in the field is to attempt to ascertain what these affects or carriers of significance might be, while accepting an absolute exclusion from these worlds that maintains us, paradoxically, in an intimate proximity.

\section{$5 \quad$ Surface Effects}

Many of the claims of the Emergence and Design Group appear radical, offering transformative potentials for a more sustainable world and an architecture that is living organism. Ingraham explains this potential in terms of the surface effect, "the surface meshes of computational architectures carry the potential not only for acting as some kind of living surface but also for making profound fields of reparation beyond their immediate boundaries" (29). That is to say, the material management of surface architecture, digitally augmented, might extend itself through these new technologies to attain more environmentally responsive systems. This is a key aspect of the argument forwarded by the Emergence and Design Group, who explain that most form-finding methods result in curved geometries and smoothly differentiated surfaces, as surface curvature allows structural capacity and opportunities for controlling orientation in response to environmental factors (2006: 31). Differentiation here embraces the unique and novel form (37), as well as its appropriate site placement, a form increasingly available as built product through computer manufacturing means. Finally, the curved surface interfaces well will 'nature' in more than a merely metaphorical way.

To this architectural surface of smooth differentiation what needs to be added are new relationships of intertwinement between human and other kinds of bodies and life forms, the immediate, mostly porous boundaries beyond which the environment and associated pressures insist. From the apparent rise of a techno-biological paradigm a new metaphysics, or perhaps ontology of the surface (as distinct from verticality, horizontality, and volume) needs to be articulated (see Ingraham). This surface writhes beneath the touch, is animated, suffers peristaltic movements and evolves over time only to pass resolutely away. The theoretical electronic domain of our computer software-hardware apparatuses shows us this process, but are such processual adventures enough? Guattari in The Three Ecologies argues for an ecosophy that accounts not just for the environment, but for social relations and human subjectivity $(2000,28)$. Guattari argues that an approach to environmental concerns cannot forget the co-presence of shifting social relations as well as the transformative potential of human subjectivity in construction, or components of subjectification (36). It should also be noted that Guattari argues for another paradigm altogether, an aesthetic paradigm, which is also a processual paradigm $(1995,106)$. Importantly this paradigm always responds by way of a double, and asymmetrical surface articulation between infinite speeds of thought as they pertain, on the one side, to a plane of immanence and, on the other side, to the emergence of finite, manifested states of things and bodies.

The importance of the formulation of a plane of immanence is that it challenges any point of view supposedly achieved from transcendent heights, and instead supports differential points of view as well as the relations between these. Across this plane disjunctive syntheses oblige us to admit difference at every step, that all life progresses erratically, emerging according to a mixture of chance and necessity by way of difference, and that difference emerges, approaches, clenches in an embrace with the other only to withdraw again into an inaccessible outside, a pre-individual, pre-architectural, pre-philosophical zone that allows our very blind durations and processes to continue to unfurl. Foucault describes a life proceeding through error. The question remains, how do we make the best of the encounter in the midst of which we find ourselves? How do we make the best out of what happens to us, however seemingly happenstance? The new biological paradigm offered by the Emergence and Design Technologies might at first seem to open up a radical new future for the designer, but in fact it is not radical enough when it comes to framing political and ethical implications and the very ontological transformation of the agents under consideration (architect, inhabitant, engineer, architecture's own array of conceptual persona). At worst we arrive at a state that can be called the banality of the digital. We are adept in our management of technology, it is our milieu, at least for the initiated. That we can mix techno-scientific motifs with architectural processual moves does not mean that we can identify pressing contemporary problems, or ask astute questions. 
The disjunctive synthesis admits difference as fundamental, but achieves this while maintaining the condition of heterogeneous continuity. "In short" Deleuze explains in his book Bergsonism "the characteristic of virtuality is to exist in such a way that it is actualised by being differentiated and is forced to differentiate itself, to create lines of differentiation in order to be actualised" (97). Differenc/tiation is vital, a vital difference; "Evolution is actualisation, actualisation is creation" (98). The dynamic threshold between the virtual and the actual determines that processes of actualisation develop in such a manner that they bear no relation of resemblance to the virtual. The virtual is that which cannot be represented, and yet which conditions the creative turn toward what comes to be actualised. Processes of actualisation, which are conditioned by the virtual, do not then negate or deny the virtual in becoming different, but erupt as a positive and creative manifestation of virtual forces, or what Deleuze, after Bergson, identifies as élan vital (1988a, 103). What forces the interminable irruption of life-matters as manifested in the hundreds of millions of ever-differentiating organic-inorganic life-forms in formation that swarm this planet? Where the virtual pertains to a Whole, for instance, the whole of the plane of immanence, or transcendental field, actualisations create an irreducible pluralism, erupting here and there as so many different life forms, constructing multitudinous points of view on as many environment-worlds. Things change, encounters lead us this way and that, the ethical question becomes, how do we make the best of what happens to us? How do we make the most the event, which necessarily catches us up? This can be applied to the apparently 'automatic' processes set in action through the implementation of genetic algorithmic software. The designer continues to act, deploying an automatic technique that has necessarily been framed according to determined criteria. Though we might continue to ask who or what has this designer become? The Australian philosopher, Rosalyn Diprose reminds us that ethics is derived from the Greek word, ethos, meaning dwelling, also habitat, or a place defined as such through our habits. Dwelling is composed of bodily habits, but "to belong to and project out from an ethos is to take up a position in relation to others"(2005 238). An intrinsic awareness of the body allows us to make a place and to make this place in relation to others, that is, to effectively construct an ethics. And it is good to be reminded that "A body can be anything; it can be an animal, a body of sounds, a mind or an idea; it can be a linguistic corpus, a social body, a collectivity" (1988b, 127). It is into this interminable swarming movement of the disjunctive syntheses of difference in which we find ourselves inextricably in the midst. This is where (post)digital architects dare to tread. The curious and simple fact of the matter is that, even through mundane and everyday praxis the designer already operates in the midst of things, handling through the deployment of different techniques one vicissitude after another.

\section{$7 \quad$ References}

Agamben, Giorgio. The Open: Man and Animal (Trans. Kevin Attell). Stanford, Cal.: Stanford University Press, 2004.

Canguilhem, Georges. The Normal and the Pathological (Trans. Caroline R. Faecett and Robert S. Cohen). New York: Zone Books, 1991.

Deleuze, Gilles. Pure Immanence: Essays on A Life (Trans. Anne Boyman). New York: Zone Books, 2001.

Deleuze, Gilles. Essays Critical and Clinical (Trans. Daniel W Smith). London: Verso, 1998.

Deleuze, Gilles. Difference and Repetition (Trans. Paul Patton). New York: Columbia University Press, 1994.

Deleuze, Gilles. The Fold: Leibniz and the Baroque (Trans. Tom Conley). Minneapolis: University of Minnesota Press, 1993.

Deleuze, Gilles. Expressionism in Philosophy: Spinoza (Trans. Martin Joughin). New York: Zone Books, 1992.

Deleuze, Gilles. The Logic of Sense (Trans. Mark Lester and Chrales Stivale). New York: Columbia University Press, 1990.

Deleuze, Gilles. Bergsonism (Trans. Hugh Tomlinson and Barbara Habberjam). New York: Zone Books, 1988a.

Deleuze, Gilles. Spinoza: Practical Philosophy (Trans. Robert Hurley). San Francisco: City Lights Books, 1988b. 
Deleuze, Gilles and Félix Guattari. A Thousand Plateaus: Capitalism and Schizophrenia (Trans. Brian Massumi). London: University of Minnesota Press, 1987.

Diprose, Rosalyn. "A 'Genethics' that Makes Sense: Take Two" in Margit Shildrik and Roxanne Mykitiuk, eds. Ethics of the Body: Postconventional Challenges. Cambridge, Mass: MIT Press, 2005.

Diprose, Rosalyn and Robyn Ferrel. Cartographies: Poststructuralism and the Mapping of Bodies. St Leonards, NSW: Allen and Unwin, 1991.

Foucault, Michel. Aesthetics, Method and Epistemology (Trans. Robert Hurley et al). Lodnon: Penguin, 1994.

Foucault, Michel. The Order of Things: An Archaeology of the Human Sciences (Trans. Tavistock Publications). London: Routledge, 1974.

Frazer, John. An Evolutionary Architecture. London: Architectural Association, 1995.

Guattari, Félix. Chaosmosis: An Ethico-Aesthetic Paradigm (Trans. Paul Bains and Julian Pefanis). Sydney: Power Publictions, 1995.

Guattari, Félix. The Three Ecologies (Trans. lan Pindar and Paul Sutton) London: The Athlone Press, 2000.

Hensel, Michael and Achim Menges, eds. Morpho-Ecologies. London: AA Publications, 2006.

Ingraham. Catherine. Architecture, Animal, Human: The Asymmetrical Condition. London: Routledge, 2006.

Pearson, Keith-Ansell. Viroid Life: Perspectives on Nietzsche and the Transhuman Condition. London: Routledge, 1997.

Smith, Daniel W. "Introduction: "A Life of Pure Immanence": Deleuze's "Critique et Clinique" Project" in Gilles Deleuze, Essays Critical and Clinical (Trans. Daniel W. Smith and Michael A. Greco). New York: Verso, 1998.

Spuybroek, Lars, ed. NOX. London: Thames and Hudson, 2004.

Weinstock, Michael, Achim Menges, Michael Hensel, guest eds. AD: Emergence: Morphogenetic Design Strategies. Chichester: Wiley-Academy, 2004.

Weinstock, Michael, Achim Menges, Michael Hensel, guest eds. AD: Techniques and Technologies. Chichester: Wiley-Academy, 2006.

Zaera, Alejandro, Farshid Moussavi. Foreign Office Architects. Phylogenesis : foa's ark, Barcelona: Actar, 2003. 